\title{
The Effectiveness of a Tablet Computer-aided Intervention Program for Improving Reading Fluency
}

\author{
Ahmet Bilal Özbek ${ }^{1, *}$, Alev Girli ${ }^{2}$ \\ ${ }^{1}$ Faculty of Educational Sciences, Ankara University, Turkey \\ ${ }^{2}$ Buca Faculty of Education, Dokuz Eylul University, Turkey
}

Copyright $\mathrm{O} 2017$ by authors, all rights reserved. Authors agree that this article remains permanently open access under the terms of the Creative Commons Attribution License 4.0 International License

\begin{abstract}
The purpose of this study is to determine the effectiveness of a tablet computer-aided intervention program for improving reading fluency. It also investigates the opinions of students and parents about this intervention by using skill- and performance-based techniques, which have been investigated qualitatively. Three students with a learning disability who are in the third or fourth grades participated in the study. The multiple baselines across participants design which is one of the single-subject experimental models has been used as an experimental design and results are presented with graphics. The findings show that the tablet computer-aided intervention program improved the reading fluency of the students with a learning disability. According to the qualitative data, the students' views about the tablet computer-aided reading fluency intervention were generally positive, indicating that this study was fun and motivated them to study. Although the parents had concerns that studying with a tablet could be perceived as a means of entertainment, they also thought the intervention was effective and wanted their children to have access to a tablet computer for educational purposes.
\end{abstract}

Keywords Tablet Computer, Reading Fluency, Learning Disability, Reading Difficulties

\section{Introduction}

In today's world, mobile devices are everywhere. Children start to use these devices from a very early age, with the time they spend looking at a screen outweighing their experiences with printed materials [1]. Indeed, technology has become an important part of our daily life, with incredible developments having taken place in the last decade alone. It is impossible to avoid technology, but it is possible to find beneficial ways to use it. As a consequence of the Project Fatih educational technology movement in Turkey, schools are now using technological devices, such as smart boards and tablet computers [2]. When examining national education statistics, we can see that there are many students with special needs who are attending public schools in the context of inclusive education [2]. Considering the principle of 'equality of opportunity,' students with special needs should benefit from all the new technological facilities to the same extent as their peers without special needs. To achieve this goal, new studies about technology use in special needs education are required.

Technology use in reading studies started with the use of audio and video recordings, as well as devices such as computers, e-readers, mp3 players and, more recently, tablet computers, in combination with various methodologies. Nowadays, there is a growing interest in technology use in education. There are studies showing that assistive technologies can have a positive impact on the performance of students [4-5]. Technological devices, such as tablet computers, mobile devices, mobile applications and other software can be useful for developing students' reading fluency, especially students with reading difficulties [5-6-7]. On the other hand, using technology has been found to be effective in increasing the motivation of students when presented with reading tasks [8-9-10].

Children with a learning disability form the majority group of those with reading difficulties, as well as those students with special needs who participate in inclusive education [11]. Children with a learning disability are defined as individuals whose success in reading, mathematics or written expression tests is significantly low considering their intelligence quotient and grade levels [12]. Reading disorder (dyslexia) is one of the learning disability subgroups, with reading fluency and comprehension problems being the common challenges faced by students in this category [13]. The common primary concerns during reading are related to the visual vocabulary, decoding, and reading word groups and sentences quickly and automatically [13]. Reading is the analysis and interpretation of written or printed symbols according to certain rules [14]. As can be understood from the description of Ozmen [14] reading has two main components as decoding and 
comprehension, while the decoding of symbols is related to fluent reading. Kuhn, Schwanenflugel and Meisinger [15] identified reading fluency as a skill that makes interference easier and includes accurate reading, automation and prosody, which are confirmed by proper pronunciation and appropriate intonation when reading aloud, as well as they affect the reading comprehension both when reading silently and aloud. It has been stated that improvements in reading fluency is needed for students to be good readers [16]. Reading fluency represents a main component of reading skills, with a positive and significant relationship existing between reading fluency and reading comprehension [17].

Final goal of reading instruction is comprehension and it is accompanied by decoding and fluency development [18]. A good reading comprehension performance is related with fluent reading skills of a student [19]. Reading fluency is defined as the accurate, fast, effortless reading with appropriate prosody [20]. When reader spends too much cognitive effort for decoding the text, focusing on the meaning and making inferences get harder [21]. Low reading fluency performance makes it hard for reader to keep information in working memory, and this creates problems on comprehension because the reader can't create relations between information units [13]. Effortless reading and appropriate speed are very important for comprehension and there are many studies showing the relation between fluency and comprehension [17-22-23].

There is a large body of research on reading fluency and the effective intervention techniques used to increase reading fluency among students with special needs. These techniques include repeated reading, pre-listening, performance feedback, rewards, paired reading, rhyming texts, flashcard word drills, corrective feedback, readers' theater and class-wide counseling [16-24-25-26-27-28-29-30-31]. There are two types of reading fluency intervention techniques. Skill-based techniques contain some aspects of teaching and practicing skills. In this process, students play an active part. For example, repeated reading is a skill-based technique, in which students are asked to read a text multiple times. Performance-based techniques are related to student's reading performance. For example, performance feedback and rewards are frequently used as part of performance based techniques [32]. In this study, skill- and performance-based techniques are used in combination.

Repeated reading, which allows the reader to read the same text at least three times, is one of the most commonly used methods [27] and considered to increase reading fluency [24-30-34-35-36]. It has been observed in recent years that technology use in the context of pre-listening interventions has become widespread. The studies in which recorded readings are used as a model have given hope in terms of making great progress in improving reading fluency and overall reading abilities [37-38]. The performance feedback technique, which is one of the performance-based techniques, involves providing a statement following the reading by the student. This technique has been shown to motivate students and help to improve reading fluency when used with repeated reading [32]. Another performance-based technique involves giving an reward to a student when they reach the expected level of performance, which has been shown to be effective at improving reading fluency when used with techniques such as repeated reading and error correction [34-39-40].

Reading fluency intervention techniques can be applied alone or together as an intervention package. That being said, the number of the studies carried out in Turkey on reading fluency [34-41-42-43-44-45] and the advantages of using technology to improve reading fluency [46-47] is insufficient. Existing reading fluency studies have been shown to concentrate on specific diagnosis groups such as individuals with intellectual disability and visual disability highlighting the need for new studies on different diagnosis groups [48]. No study has yet been conducted on improving reading fluency among Turkish children with a learning disability, while studies on technology use in reading studies simply compare electronic media and printed materials, as well as consider the thoughts of students in an electronic reading environment [49-50-51].

As such, it is clear that there is a need for studies that combine technology with effective practices. In this study, we tried to use effective reading fluency interventions with tablet computers. Therefore, the study finding should inform future studies in this area and further contribute to the special education field.

The purpose of this study is to determine the effectiveness of a tablet computer-aided reading fluency intervention, which contains skill- and performance-based techniques on the reading fluencies of third and fourth grade students with a learning disability. Repeated reading, pre-listening, performance feedback and reward techniques were used in the intervention. In order to achieve this objective, answers were sought to the following questions.

a. Is the reading fluency intervention effective in increasing the number of correct words read per minute among the students with a learning disability?

b. Is the reading fluency intervention effective in decreasing reading mistakes per minute among the students with a learning disability?

c. Is the reading fluency intervention effective in increasing the number of correct words read and decreasing the reading mistakes per minute among the students with a learning disability after seven days and 14 days?

d. What are the opinions of the students with a learning disability and their parents about the intervention?

\section{Method}

\subsection{Research Model}

Due to the difficulty in reaching out to a sufficient number of students with a learning disability diagnosis for a full 
experimental model, the study was carried out according to the multiple baselines across participants' design which is one of the single-subject experimental research models. In this model, baseline data are collected simultaneously from all subjects. When data are stable at the baseline, implementation of the independent variable is initiated with the first subject. In the meantime, baseline data continue to be collected from other subjects. When the criterion is met for the first subject, it is implemented for the second subject. This process is repeated for the third subject [52].

\subsection{Participants}

Three ( $\mathrm{n}=3$ ) students (two boys and one girl) participated in the research. The pseudo names were used for the participants. The participants were selected according to: age, grade level, being diagnosed with a learning disability and level of reading performance. Participant selection criteria were: being diagnosed with a learning disability in a university hospital, showing significantly low reading fluency compared to the grade level, and being between eight and 10 years old. All the participants' files were examined and reading fluency assessments carried out before the experimental phase. In the pre-assessments, similar texts were used and results were evaluated according to the participants' grade levels [53]. The students were found to be significantly below the grade level selected for the study.

Ece is a female student, aged eight years and five months old, with a special learning disability diagnosis, who attends elementary school in third grade. The objectives for reading difficulties are included in her individualized education plan (IEP). While there is a tablet computer for common use in Ece's home, her access to it is restricted by her family.

Utku is a male student, aged nine years and two months old, with a special learning disability diagnosis, who attends elementary school in fourth grade. The objectives for reading difficulties are included in his IEP. While there is a tablet computer for common use in Utku's home, his access to it is restricted by his family.

Serif is the other male student, aged nine years and one month old, with a special learning disability diagnosis, who attends elementary school in the fourth grade. The objectives for reading difficulties are included in his IEP. While Serif has his own tablet computer, his family use it as a reinforcer for his study behavior. His ability to use the tablet computer is very high.

\subsection{Independent Variable}

The independent variables for this study are pre-listening, repeated reading, performance feedback and reward techniques using tablet computers. We referred to this 'package' as a tablet computer-aided intervention. In intervention sessions, students listened to the model reading on the tablet before reading it. After that, they read the same text three times from the tablet computer. Students' first readings were recorded, while they listened to their own readings between the first and second reading. After every reading, the researcher gave performance feedback to the students and explained how many words they read correctly. Following the third reading, the researcher stated that the session was over and gave a reward to the student. All the intervention sessions followed the same steps and took place in a quiet room. When a participant showed a $70 \%$ increase in three consecutive sessions, the intervention phase ended.

\subsection{Dependent Variable}

The dependent variables for this study are words read correctly per minute and reading mistakes made per minute by the students while reading passages.

\subsection{Data Collection Tools}

There were 23 narrative reading passages, which correlate with the relevant grade level approved by two faculty members of the Turkish Literature Department, used in the study. The reading texts were composed of texts without images and length of the texts were between 100 and 120 words. All the texts were written in Times New Roman font. The texts were read aloud and recorded on the tablet computer by the first researcher with the aid of sound recording software as part of the pre-listening intervention technique. The brand of tablet computer used in the study was the Apple iPad, while the texts were displayed via the Adobe Reader application. Data collection tools took the form of performance recording tables developed separately for each phase of the experimental process by the researchers, with records made after each reading of the texts by the researcher and the resulting data transferred to these tables. The interviews consisted of seven questions for the participants and five for the parent, which were prepared by the researchers in line with the social validity data used.

\subsection{Procedure}

The data of the study were collected during the baseline, intervention and follow-up stages. The total number of sessions was 13 for Ece (Participant 1), 13 for Utku (Participant 2) and 15 for Serif (Participant 3). The opinions of the participants and parents concerning the study were identified through interviews once the data collection sessions were completed. The sessions, lasting an average of 20 minutes, were held with the participants once a week in the special education center in which they received support training. All the intervention and evaluation sessions were conducted by the first researcher, who holds a bachelor degree in teaching those with a intellectual disability and was doing a master's degree in the special education field.

At the baseline stage, data were collected for each participant until stable data was obtained for the performance 
level. The participants were asked to read the text provided on the tablet computer after the study had been described. The researcher instructed each participant by saying 'Do your best reading,' with the reading performance in the course of a minute recorded.

The 'pre-listening + repeated reading + performance feedback + reward' techniques were included in the intervention sessions. The study was explained to the students, after which the recording of the pre-listening reading was played, with the students asked to follow the text while listening to the reading. The students were then asked to read the text, which was recorded, while the reading performance was determined in the process. After the text was read, performance feedback was given to the students and the recording of their reading was played to them. The students were asked to listen to their own reading and follow the text, then asked to read the text for a second and a third time, while their reading performances were determined and performance feedback was given in due course. After the third reading, a reward was given to the participants in the form of tablet computer games.

The follow-up sessions were held seven and 14 days after the intervention sessions were completed, in which the participants were asked to read the texts on the tablet computer as they did during the baseline level, while their correct and incorrect readings in the course of one minute were recorded.

In order to determine the social validity of the study, interviews were conducted with each participant and their parents by using the semi-structured interviews, with a format prepared by the researchers, which were recorded after the monitoring sessions were held.

Of the video recordings of experimental sessions, 33\% were examined for inter-observer reliability and procedural fidelity. The records of the observers and the data collected by the first researcher were matched and compared, with the number of consensus points between researchers and observers divided into sum of agreements and disagreements, which were then multiplied by 100 . The inter-observer reliability of the research was calculated as $93.55 \%$. Thirty-one sessions involving video recordings, conducted by an observer, were monitored and the procedural fidelity forms were completed. As a result, the procedural fidelity of the research was determined as $100 \%$.

\section{Findings}

\subsection{Number of Correct Words Read and the Incorrect Readings per Minute}

The average of the four baseline level sessions held with
Participant 1 was determined as 23 correct and four incorrect words per minute. The condition for the completion of the intervention sessions for her was determined when at least 39 correct words were achieved in three consecutive sessions. The average for her last intervention session was 55 correct words per minute. It was determined that she read 32 more correct words than the baseline level. The number of incorrect readings, which was four at the baseline level, showed a decrease in the intervention sessions. She only made one incorrect reading in both follow-up sessions.

The average of the seven baseline level sessions held with Participant 2 was determined as 41 correct and one incorrect words per minute. The condition for the completion of the intervention sessions for him was determined when at least 69 correct words were achieved in three consecutive sessions. The average of his last intervention was 69 correct words per minute. It was determined that he read 28 more correct words than the baseline level. The number of incorrect readings by him was stable.

The average of the nine baseline level sessions held with Participant 3 was determined as 19 correct and one incorrect words per minute. The condition for the completion of the intervention sessions for him was determined when at least 32 correct words were achieved in three consecutive sessions. The average of his last intervention session was 45 correct words per minute. It was determined that he read 26 more correct words than the baseline level. The number of incorrect readings by him was stable.

\subsection{Follow-up Sessions}

Participant 1 read out 39 correct words in the first monitoring session and 35 correct words in the second monitoring session held after the intervention sessions. When the baseline level and final monitoring sessions are compared, the correct words read per minute by her showed an increase of 12 words or $52 \%$.

Participant 2 read out 58 correct words in the first monitoring session and 50 correct words in the second monitoring session held after the intervention sessions. When the baseline level and final monitoring sessions are compared, the correct words read per minute by him showed an increase of nine words or $22 \%$.

Participant 3 read out 34 correct words in the first monitoring session and 30 correct words in the second monitoring session held after the intervention sessions. When the baseline level and final monitoring sessions are compared, the correct words read per minute by him showed an increase of 11 words or $58 \%$. 
B $\quad$ I $\quad$ F

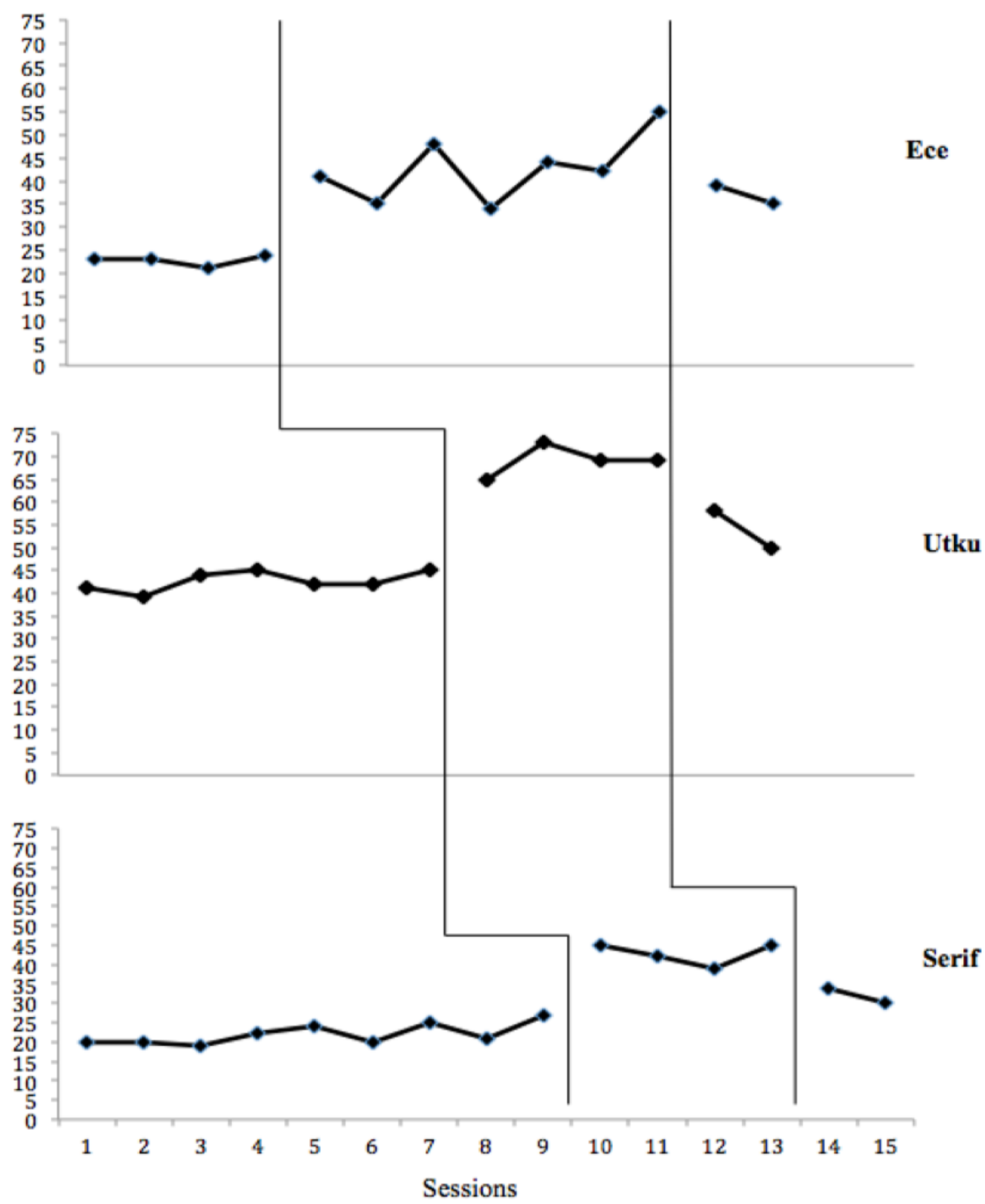

Graph 1. Words Read Correctly by Participants

\subsection{Social Validity Findings}

When the answers of the participants were examined, it was noted that the students enjoyed reading from tablets and intended to continue reading in the same way with their own tablet computers. When asked what they thought about listening to their own readings, each student said they did not like this experience. Their thoughts about reading from a tablet were positive, with the first researcher observing that they were highly motivated when reading in this way. When the answers of the parents were examined, it was noted that they had observed a change in their child's motivation with regard to reading; further, they were informed by their child that they were excited about studying with the researcher, 
whom they called a 'new elder brother.' Their ideas about using tablet computers for academic purposes were generally positive.

\section{Discussion}

The purpose of this research was to determine the effectiveness of a tablet computer-aided intervention program for improving reading fluency among students with a learning disability. An increase was observed in the number of correct words read per minute by the three participants in the intervention phase, compared to the baseline, which is a consistent finding with studies conducted previously [5-9-36-40-54-55-56]. However the performance of participants decreased in the follow-up sessions. Possible explanations for this could be the number of interventions carried out and the frequency of interventions. Interventions were conducted once a week and lasted only 20 minutes. The male participants, Serif and Utku, received only four intervention sessions, while the female participant, Ece, received seven intervention sessions. We wanted to keep the intervention phase short in order to ensure experimental control. Another possible explanation could be the students' difficulty in following the text while pre-listening because a highlighted text feature was not used. Furthermore, when interviewed, the participants reported that it was hard to catch up with the model reading. As a result, we can say that a reading fluency intervention with tablet computers does not offer significant benefits, as the findings only show that it is slightly effective.

When the findings concerning incorrect reading levels are examined, the number of the incorrect readings by a participant per minute was seen to decrease. While it was observed that participants continued to give incorrect readings at the same level as the baseline level, incorrect readings were not repeated in each session; indeed, there was only one incorrect reading per minute. According to these results, the intervention program can be said to be effective in reducing the number of incorrect readings per minute by students. There are similar studies which showed similar findings [37-40-57-58].

The reading fluency performance of the participants appeared to change at different rates. This situation could be explained by the different baseline levels of the students. While the reading fluency performances of Ece and Serif showed an improvement higher than existing performances by up to $150 \%$, the number of correct words read per minute by Utku only showed an increase of $70 \%$. When the findings of the monitoring and the baseline performances are compared, it was determined that Ece showed increase of 12 words or $52 \%$, Utku showed an increase of nine words or $22 \%$, and Serif showed an increase of 11 words or $58 \%$. It can be seen that, as the baseline level performance of the students improves, the effect ratio of the intervention decreases accordingly. It is possible to find similar results in existing research studies [59-60]. In addition, due to her state of health, Ece showed an inconsistent level of performance during the intervention sessions, which is why she received three more interventions.

It is known that children with a reading disorder display negative attitudes towards reading; indeed, they generally dislike reading. The results of the interviews conducted with the children and the observations of the researcher suggest that the students enjoyed studying as part of the tablet computer-aided reading fluency intervention program, leading to a high level of motivation: a finding that is similar to the results in Sheppard's [61] study. The participants and their parents stated that after the study there were positive changes in their former reading performances. These results can be interpreted as an indicator that computer-aided studies may be used effectively in order to improve the reading fluency of children with reading disabilities [8-9-10-47-59-62] When the interview data with the participants were compared, it was found that they were much more motivated to read when technological devices were used [49-50-51].

This is a preliminary study in Turkey, and it aims to create a pathway to more advanced research in the future. Further studies on this topic could look at more complexly constructed software. It was observed that the participants in this study, despite being diagnosed with a learning disability, did not seem to have any difficulty in using tablet computers as a reading tool, to the extent that they could use them independently without the help of the first researcher in the final sessions. It was also determined that the participants were eager to read from the tablets, while they and their parents thought that the tablets were useful and applicable for the purposes of education. The effectiveness of mobile applications with digital features, such as highlighted text, model readings and voice recognition, could be investigated in further research. Meanwhile, this study is limited by the use of narrative passages, and the involvement of only three children with a learning disability and their reading fluency performances.

\section{REFERENCES}

[1] Plowman, L., McPake, J., \& Stephen, C. (2010). The technologisation of childhood? Young children and technology in the home. Children \& Society, 24(1), 63-74.

[2] Milli Eğitim Bakanlığı. (2012). "Fatih Projesi.” Erişim Tarihi: 02 Ekim 2013, Milli Eğitim Bakanlığı A $\breve{g}$ Sitesi:http://fatihprojesi.meb.gov.tr/tr/icerikincele.php?id=6

[3] Hecker, L., Burns, L, Elkind, J., Elkind, K., \& Katz, L. (2002). Benefits of assistive reading software for students with attention disorders. Annals of Dyslexia, 52, 244-272.

[4] Hetzroni, O. E., \& Shrieber, B. (2004). Word processing as an assistive technology tool for enhancing academic outcomes of students with writing disabilities in the general classroom. Journal of Learning Disabilities, 37(2), 143-154. 
[5] Ortlieb, E., Sargent, S. ve Moreland, M. (2014). Evaluating the Efficacy of Using a Digital Reading Environment to Improve Reading Comprehension within a Reading Clinic, Reading Psychology, DOI:10.1080/02702711.2012.683236

[6] Raskind, M. H., \& Higgins, E. L. (1998). Assistive Technology for Postsecondary Students with Learning Disabilities An Overview. Journal of Learning Disabilities, 31(1), 27-40.

[7] Raskind, M. H., \& Higgins, E. L. (1999). Speaking to read: The effects of speech recognition technology on the reading and spelling performance of children with learning disabilities. Annals of Dyslexia, 49(1), 251-281.

[8] Benevides, T. L. (2013). Examining Reading Processes and Engagement of Struggling and Proficient Readers when Using iPads, Yayınlanmamış Doktora Tezi, University of Toronto.

[9] Coleman, M. B., ve Wolff Heller, K. (2010). The Use of Repeated Reading with Computer Modeling to Promote Reading Fluency with Students Who Have Physical Disabilities. Journal of Special Education Technology, 25(1), 29.

[10] MacEwen, J. (2013). School Students with Learning Disabilities. Yayınlanmamış Yüksek Lisans Tezi, Rowan University College of Education.

[11] IDEA, (2009). 2009 Child Count, Ages 6-21, Retrieved from www.IDEAdata.org.

[12] American Psychiatric Association (2013). DSM 5: Diagnostic and statistical manual of mental disorders (5th ed). Arlington, VA: American Psychiatric Association.

[13] Chard, D. J., Vaughn, S., \& Tyler, B. J. (2002). A synthesis of research on effective interventions for building reading fluency with elementary students with learning disabilities. Journal of learning disabilities, 35(5), 386-406.

[14] Guzel-Ozmen, R. (2005). Ogrenme Guclugu Olan Ogrencilerin Okuma Hizlarinin Metinlerde Karsilastirilmasi. Egitim ve Bilim Dergisi.136, 30, 25-30.

[15] Kuhn, M. R., Schwanenflugel, P. J., \& Meisinger, E. B. (2010). Aligning theory and assessment of reading fluency: Automaticity, prosody, and definitions of fluency. Reading Research Quarterly, 45(2), 230-251.

[16] Carnine, D. W., Silbert, J., Kame'enui, E. J. \& Tarver, S. G. (2004). Direct instruction reading (4th ed.). Upper Saddle River, NJ: Prentice Hall/Merrill.

[17] Brinker, A. (2013). Is There a Relationship Between Reading Fluency and Reading Comprehension? Yayınlanmamış Doktora Tezi, Northwest Missouri State University.

[18] Graham, L., \& Bellert, A. (2005). Reading comprehension difficulties experienced by students with learning disabilities. Australian Journal of Learning Difficulties, 10(2), 71-78

[19] Adlof, S.M., Catts, H. W., \& Lee, J. (2010). Kindergarten predictors of second versus eighth grade reading comprehension. Journal of Learning Disabilities, 43, 332-345. doi: $10.1177 / 002219410369067$.

[20] Perfetti, C. A. (1984). Some reflections on learning and not learning to read. Remedial and Special Education, 5(3), 34-38.

[21] Shaywitz, B. A., Fletcher, J. M., Holahan, J. M., Shneider, A.
E., Marchione, K. E., Stuebing, K. K. (1995). Innerrelationships between reading disability and attention-deficit/hyperactivity disorder. Child Neuropsychology, 1, 170-186.

[22] Applegate, M. D., Applegate, A. J., \& Modla, V. B. (2009). "She's my best reader; she just can't comprehend": Studying the relationship between fluency and comprehension. The Reading Teacher, 62(6), 512-521.

[23] Meisinger, E. B., Bradley, B. A., Schwanenflugel, P. J., Kuhn, M. R., ve Morris, R. D. (2009). Myth and reality of the word caller: The relation between teacher nominations and prevalence among elementary school children. School Psychology Quarterly, 24(3), 147.

[24] Faver, S. (2009) Repeated Reading of Poetry Can Enhance Reading Fluency. The Reading Teacher, Vol. 62,(4), 350-352.

[25] Gut, D. M., Bishop-Goforth, J. ve Farmer, T. W. (2004). The school engagement project: Academic engagement enhancement. Preventing School Failure, 48, 4-9.

[26] Keehn, S. (2003). The effect of instruction and practice through readers' theatre on young readers' oral reading fluency. Reading Research and Instruction, 42, 40-61.

[27] Lock, R. H., ve Welsch, R. G. (2006). Increase oral reading fluency. Intervention in School and Clinic, 41(3), 180-183.

[28] O’Connor, R. F., Bell, K. M. ve Harty, K. R. (2002). Teaching reading to poor readers in the intermediate grades: A comparison of text difficulty. Journal of Educational Psychology, 94, 474-485.

[29] Rasinski, T., Rupley, W. H., ve Nichols, W. D. (2008). Synergistic phonics and fluency instruction: The magic of rhyming poetry. New England Reading Association Journal, 44(1), 9-15.

[30] Staudt, D. H. (2009). Intensive word study and repeated reading improves reading skills for two students with learning disabilities. The Reading Teacher, 63(2), 142-151.

[31] Wilfong, L. G. (2008). Building Fluency, Word-Recognition Ability, and Confidence in Struggling Readers: The Poetry Academy. The Reading Teacher, 62(1), 4-13.

[32] Eckert, T. L., Ardoin, S. P., Daisey, D. M., \& Scarola, M. D. (2000). Empirically evaluating the effectiveness of reading interventions: The use of brief experimental analysis and single case designs. Psychology in the Schools, 37(5), 463-473.

[33] Samuels, S. J. (2006). Reading Fluency: Its past, present and future. In T. V. Rasinski, C. L. Z. Blachowicz ve K. Lems (Ed.) Fluency Instruction: Research Based Best Practices (sy. 7-20). New York; London: Guilford.

[34] Çevik,Ö. (2006) Zihinsel Yetersizliği Olan Öğrencilerin Sesli Okuma Hizlarının Arttırılasında Okuma Öncesi ve Okuma Sonrası Sağaltım Tekniklerinin Farklılaşan Etkililiği Yayımlanmamış Yüksek Lisans Tezi.Gazi Üniversitesi, Eğitim Bilimleri Enstitüsü, Ankara.

[35] Mercer, C.D., Campbell, K.U., Miller, M.D., Mercer, K.D. ve Lane, H.B. (2000). Effects of a reading fluency intervention for middle schoolers with specific learning disabilities. Learning Disabilities Research \& Practice, 15, 179-189. 
[36] Morra, J., \& Tracey, D. H. (2006). The impact of multiple fluency interventions on a single subject. Reading Horizons, 47(2), 5 .

[37] Rasinski, T. V., Reutzel, D. R., Chard, D. ve Linan-Thompson, S. (2011). Handbook of reading research. Choice Reviews Online, 4(10), 28-5764.

[38] Schneps, M. H., Thomson, J. M., Sonnert, G., Pomplun, M., Chen, C., \& Heffner-Wong, A. (2013). Shorter Lines Facilitate Reading in Those Who Struggle. PloS one, 8(8), e71161.

[39] Chafouleas, S. M., Martens, B. K., Dobson, R. L.,Weinstein, K. S., \& Gardner,K. B. (2004). Fluent reading as the improvement of stimulus control: Additive effects of performance-based interventions to repeated reading on students' reading and error rates. Journal of Behavioral Education, 13, 67-81.

[40] Eckert, T. L., Ardoin, S. P., Daly, E. J., \& Martens, B. K. (2002). Improving oral reading fluency: A brief experimental analysis of combining an antecedent intervention with consequences. Journal of applied behavior analysis, 35(3), 271-281.

[41] Baydık, B., Ergül, C., Kudret, Z.B. (2012) Okuma Güçlüğü Olan Öğrencilerin Okuma Akıcılığı Sorunları ve Öğretmenlerinin Bu Sorunlara Yönelik Öğretim Uygulamaları Elementary Education Online, 11(3), 778-789, 2012. [Online]: http://ilkogretim-online.org.tr/, retrieved on 02.01.2013.

[42] Dağ, N. (2010). Okuma Güçlügünün Giderilmesinde 3P Metodu ile Bosluk Tamamlama (Cloze) Tekniginin Kullanimi Üzerine Bir Çalisma. Ozel Egitim Dergisi 11(1): 63-77.

[43] Güzel-Ozmen, R. (2011). Evaluating the Effectiveness of Combined Reading Interventions on Improving Oral Reading Fluency of Students with Reading Disabilities. Revista electrónica de investigación psicoeducativa y psicopedagógica 9(3): 1063-1086.

[44] Orçan, M. ve Özmen, E. R. (2012). Zihinsel Yetersizlikten Etkilenmiş Öğrencilerin Okuma Hızının Artırılmasında Sağaltım Paketlerinden Etkili Olanın Belirlenmesi. Ozel Egitim Dergisi, 13(1).

[45] Seçkin,Ş. (2012). Okuma Güçlüğü Olan Ve Olmayan Öğrencilerin Okuma Akıcılığı Yayınlanmamış Yüksek Lisans Tezi. Ankara Üniversitesi, Ankara.

[46] Aydemir, Z. ve Öztürk, E., Horzum, M.B. (2012). Ekrandan Okumanın 5. Sınıf Öğrencilerinin Bilgilendirici ve Öyküleyici Metin Türünde Okuduğunu Anlama Düzeylerine Etkisi. Kuram ve Uygulamada Eğitim Bilimleri,1-(14).

[47] Öztürk, E. ve Can, I. (2013). İlköğretim 5.Sınıf Öğrencilerinin Elektronik kitap okumaya ilişkin görüşleri. Türkiye Sosyal Araştırmalar Dergisi. Vol. 17 ,pp. 137 - 153, ISSN: 1301-370X, DOI

[48] Özak, H. ve Diken, İ. (2010). Zihinsel yetersizliği olan öğrencilerin işlevsel akademik becerilerine ilişkin Türkiye'de yapılan lisansüstü tezlerin gözden geçirilmesi. Özel Eğitim Dergisi, 11(1), 43-61.

[49] Baştuğ, M., \& Keskin, H. K. (2013). Okuma Becerilerinin Okuma Ortamı Açısından Karşılaştırılması: Ekran mı kâğıt mı?. Sosyal Bilimler Enstitüsü Dergisi, 16(3).
[50] Ertem, İ.S., Özen, M. (2014). Metinleri Ekrandan okumanın anlam kurma üzerine etkisi. International Journal Of Social Science, 24, 319-350.

[51] Yaman, H., \& Dağtaş, A. (2013). Ekrandan Okumanın Okumaya Yönelik Tutuma Etkisi/Impact of Screen Reading Towards Attitudes of Reading. Eğitimde Kuram ve Uygulama, 9(4), 314-333.

[52] Alberto, P. A., \& Troutman, A. C. (2009). Applied behavior analysis for teachers (8th ed.). Upper Saddle River, NJ: Merrill Prentice Hall.

[53] Erden, G., Kurdoğlu, F., \& Uslu, R. (2002). İlköğretim okullarına devam eden Türk çocuklarının sınıf düzeylerine göre okuma hızı ve yazım hataları normlarının geliştirilmesi. Türk Psikiyatri Dergisi, 13(1), 5-13.

[54] Esteves, K.J. \& Whitten, E. (2011). Assisted reading with digital audiobooks for students with reading disabilities. Reading Horizons. 51(1), 21-40.

[55] Morisoli, K. (2010). Effects of Repeated Reading on Reading Fluency of Diverse Secondary-Level Learners (Doctoral dissertation, Arizona University). Retrieved from http://arizona.openrepository.com/ arizona/handle/10150/145364

[56] Wagner, D. A., Castillo, N. M., Murphy, K. M., Crofton, M., \& Zahra, F. T. (2014). Mobiles for literacy in developing countries: An effectiveness framework. Prospects, 44(1), 119-132.

[57] Nelson, J. S., Alber, S. R., \& Gordy, A. (2004). The effects of error correction and repeated readings on the reading achievement of students with learning disabilities. Education\& Treatment of Children, 27, 186-198.

[58] Watson, M., Fore III, C., \&Boon, R. T. (2009). Corrective feedback of oral decoding errors for diverse learners with reading disabilities: The effects of two methods on reading fluency. International Journal of Special Education, 24(1), 20-31.

[59] Alber-Morgan, S. R., Ramp, E. M., Anderson, L. L., \& Martin, C. M. (2007). Effects of repeated readings, error correction, and performance feedback on the fluency and comprehension of middle school students with behavior problems. The Journal of Special Education, 41(1), 17-30.

[60] Guler, O. (2011). Turkcenin Egitimi-Ogretiminde Kuramsal ve Uygulamali Arastirmalar. Zihinsel Engelli Ogrencilerin Okuma Akiciligini Gelistirmede Hata Duzeltme, Tekrarli Okuma ve Geri Bildirim Verme Tekniklerinin Birlikte Kullaniminin Etkililigi (International Book Chapter), Eule Publishing, Germany.

[61] Sheppard, D. (2011). Reading with iPads-the difference makes a difference. Education Today, 11(3), 12-15.

[62] Swanson, L. C. (2013). Impact of iPads on Reading Fluency in a Sixth-Grade Reading Classroom (Master's thesis, Southwest Minnesota State University). Retrieved from https://www.editlib.org/p/117234/. 